\title{
Unusual Origin and Relations of the Accessory Meningeal Artery - A Case Report
}

\author{
Origen Inusual y Relaciones de la Arteria Meníngea Accesoria - Reporte de un Caso
}

Prakashchandra Shetty; Melanie Rose D'Souza \& Satheesha Nayak B.

SHETTY, P.; D'SOUZA, M. R. \& NAYAK, S. B. Unusual origin and relations of the accessory meningeal artery - A case report. Int. J. Morphol., 35(4):1348-1350, 2017.

SUMMARY: Accessory meningeal artery is a branch of the first part of the maxillary artery. It supplies the structures in the infratemporal fossa and the dura mater in the middle cranial fossa. Accessory meningeal artery arose from the middle meningeal artery, $25 \mathrm{~mm}$ below the base of the skull and entered the middle cranial fossa through the foramen ovale. The two roots of the auriculotemporal nerve looped around it. The knowledge of the variant origin and relations may be useful during the surgeries of the infratemporal fossa. It might also be useful to the radiologists.

KEY WORDS: Accessory meningeal artery; Maxillary artery; Middle meningeal artery; Infratemporal fossa.

\section{INTRODUCTION}

Accessory meningeal artery is a branch of first part of the maxillary artery. However, it might also arise from the middle meningeal artery in a few cases. Though the name is accessory meningeal artery, it predominantly supplies the muscles, and nerves of the infratemporal fossa. It enters the cranial cavity by passing through the foramen ovale. It supplies the trigeminal ganglion, sphenoid bone and the dura mater of the middle cranial fossa. We noted a variation in the level of origin of the artery. It also had unusual relations.

\section{CASE REPORT}

During our routine dissection classes for undergraduate medical students, we observed neurovascular variations in the infratemporal fossa. Accessory meningeal artery arose from the middle meningeal artery, $25 \mathrm{~mm}$ below the base of the skull and entered the middle cranial fossa through the foramen ovale by passing behind the mandibular nerve. Further, the two roots of the auriculotemporal nerve looped around it (Figs. $1 \& 2$ ). The posterior root of auriculotemporal nerve was thicker in size than its anterior root. The main trunk of the auriculotemporal nerve passed backwards, deep to the middle meningeal artery. Since the artery originated just below the skull, it did not supply the structures in the infratemporal fossa. It predominantly supplied the trigeminal ganglion, bones of the skull and the dura mater of the middle cranial fossa.

\section{DISCUSSION}

Accessory meningeal artery arises either from the first part of maxillary artery or the middle meningeal artery. Very few reports on variations of this artery have been published. According to Bergman et al., accessory meningeal artery is present in about $96 \%$ of individuals and it originates from either the middle meningeal or maxillary artery with almost equal frequency. This artery supplies branches to the medial pterygoid muscle, upper head of the lateral pterygoid, tensor veli palatini, parts of the sphenoid bone, middle cranial fossa, braches of mandibular division of the trigeminal nerve, and the otic ganglion. It has also been reported to supply the trigeminal (semilunar) ganglion in about $50 \%$ of cases. Since only 


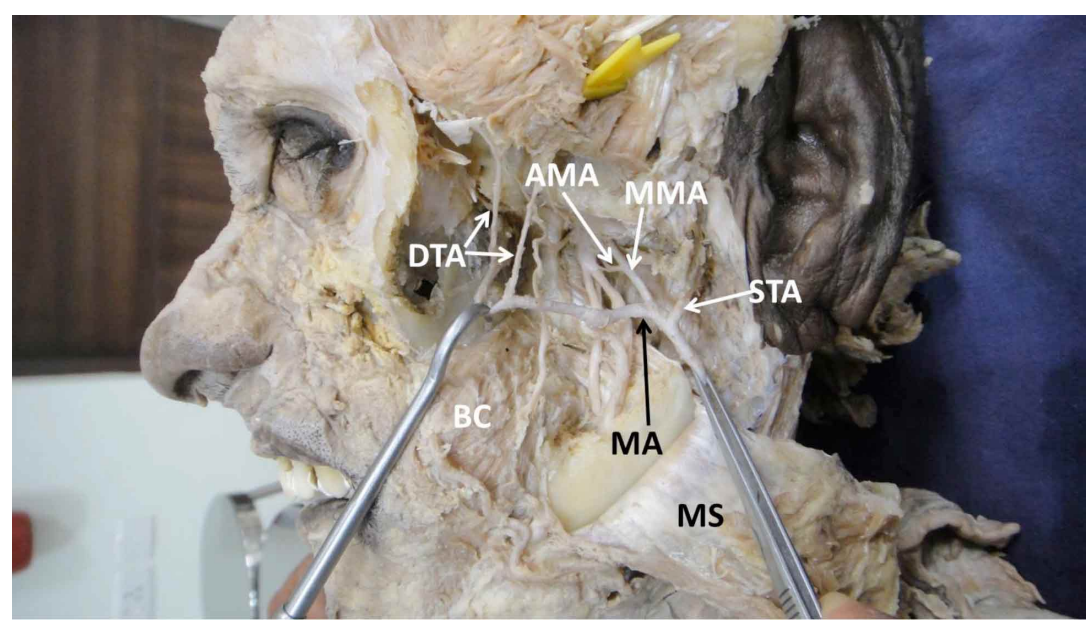

Fig. 1. Panoramic view of the dissection of the left infratemporal fossa showing the origin of the accessory meningeal artery (AMA) from the middle meningeal artery (MMA). (MS - masseter muscle; MA - maxillary artery; STA - superficial temporal artery; DTA - deep temporal arteries; BC - buccinator muscle).

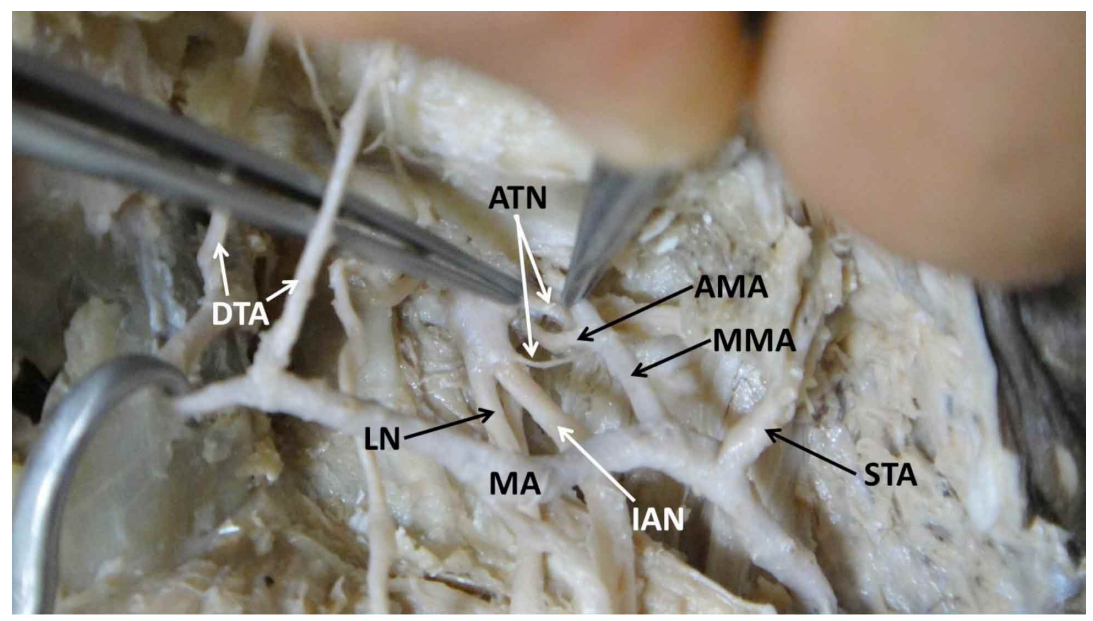

Fig. 2. Closer view of the dissection of the left infratemporal fossa showing the origin of the accessory meningeal artery (AMA) from the middle meningeal artery (MMA) Note the two roots of auriculotemporal nerve (ATN) looping around it. (MA - maxillary artery; STA - superficial temporal artery; DTA - deep temporal arteries; LN - lingual nerve; IAN - inferior alveolar nerve)

$10 \%$ of its blood reaches the cranial cavity and $90 \%$ supplies the infratemporal structures, Vitek (1989) is of the opinion that arteria pterygomeningica, or pterygomeningeal artery is the most preferred name for the artery. In the current case the artery took its origin from the middle meningeal artery, just below the skull and did not supply the infratemporal structures significantly. Hence by right we can call it as "accessory meningeal artery". The accessory meningeal artery can be identified as the arterial pedicle responsible for blood supply to meningiomas of the temporal fossa and possibly even to tumors of the trigeminal ganglion and can be demonstrated radiologically (Dilenge \& Géraud, 1976). Lasjaunias \& Théron (1976) believe that all intracranial lesions which are not strictly intracerebral should be investigated by means of selective injection of the internal maxillary artery. Rarely, the accessory meningeal artery supplies the posterior part of the nasal cavity. This fact has to be kept in mind while treating intractable posterior epistaxis with embolization of the ipsilateral sphenopalatine and facial arteries and contralateral sphenopalatine artery (Duncan \& Dos Santos, 2003). Auriculotemporal nerve is a branch of the posterior division of the mandibular nerve. It arises through two roots which loop around the middle meningeal artery before joining to form a single trunk. In the current case however, the roots of the nerve looped around the accessory meningeal artery. Embryologically, the maxillary artery and the branches develop from a vascular network in the infratemporal fossa. Initially the network is supplied by the stapedial artery and later by the external carotid artery. Subsequently, some channels of the network disappear and the remainder will form the arteries of the infratemporal region. Hence we can assume that due to some developmental errors, the auriculotemporal nerve looped around the accessory meningeal artery rather than the middle meningeal artery (Baumel \& Beard, 1961; Hogg et al., 1972). Precise knowledge of normal anatomy of infratemporal fossa and its possible variants is very useful during surgical approaches to foramen ovale such as percutaneous and lateral sublabial endoscopic approaches for the treatment of trigeminal neuralgia and for performing biopsies of lesions located in the parasellar region.

\section{CONCLUSION}

We believe that the knowledge of variations reported here might be useful for the radiologists and surgeons to minimize the possible complications of the surgeries related to infratemporal region, specifically close to the foramen ovale. 
SHETTY, P.; D'SOUZA, M. R. \& NAYAK, S. B. Origen inusual y relaciones de la arteria meníngea accesoria-Reporte de un caso. Int. J. Morphol., 35(4):1348-1350, 2017.

RESUMEN: La arteria meníngea media es una rama accesoria que emerge al inicio de la arteria maxilar. Suministra la vascularización a nivel de la fosa infratemporal y la duramadre en la fosa craneal media. En este trabajo, surgió una arteria meníngea accesoria de la arteria meníngea media, a una $25 \mathrm{~mm}$ por debajo de la base del cráneo, accediendo en la fosa craneal media a través del foramen oval. Las dos raíces del nervio auriculotemporal la rodeaban. El conocimiento de esta variación y sus relaciones pueden ser útiles durante las cirugías de la fosa infratemporal, como así también puede ser útil para los radiólogos.

PALABRAS CLAVE: Arteria meníngea accesoria; Arteria maxilar; Arteria meníngea media; Fosa infratemporal.

\section{REFERENCES}

Baumel, J. J. \& Beard, D. Y. The accessory meningeal artery of man. J. Anat., 95:386-402, 1961.

Dilenge, D. \& Géraud, G. Accessory meningeal artery. Acta Radiol. Suppl., 347:63-9, 1976.

Duncan, I. C. \& Dos Santos, C. Accessory meningeal arterial supply to the posterior nasal cavity: another reason for failed endovascular treatment of epistaxis. Cardiovasc. Intervent. Radiol., 26(5):488-91, 2003.

Hogg, I. D.; Stephens, C. B. \& Arnold, G. E. Theoretical anomalies of the stapedial artery. Ann. Otol. Rhinol. Laryngol., 81(6):86070, 1972.

Lasjaunias, P. \& Théron, J. Radiographic anatomy of the accessory meningeal artery. Radiology, 121(1):99-104, 1976.

Vitek, J. J. Accessory meningeal artery: an anatomic misnomer. A. J. N. R. Am. J. Neuroradiol., 10(3):569-73, 1989.
Corresponding author:

Dr. Satheesha Nayak B

Department of Anatomy

Melaka Manipal Medical College (ManipalCampus)

Madhav Nagar, Manipal - 576104

Udupi District

Karnataka State

INDIA

Email: nayaksathish@gmail.com

Received: 24-03-2017

Accepted: 14-07-2017 